\title{
Freezing and storage of copepod samples for the analysis of lipids
}

\author{
M. D. Ohman*
}

Marine Life Research Group 0227, Scripps Institution of Oceanography, University of California San Diego, La Jolla, California 92093-0227, USA

\begin{abstract}
Zooplankton are commonly frozen at sea in ecological studies when it is impractical to extract lipids immediately from live animals. Analysis of lipids extracted from the copepod Calanus pacificus established that freezing has negligible effects on copepod dry mass, total lipid content, or lipid composition, resulting only in slight changes in free fatty acids. However, storage for $1 \mathrm{yr}$ at $-15^{\circ} \mathrm{C}$ resulted in substantial loss of polar lipids and accumulation of free fatty acids when compared with animals stored at $-80^{\circ} \mathrm{C}$. Rapid freezing in liquid nitrogen, followed by maintenance of animals at temperatures below $-70^{\circ} \mathrm{C}$, is recommended where immediate lipid extraction is not feasible.
\end{abstract}

KEY WORDS: Lipids · Freezing $\cdot$ Zooplankton $\cdot$ Copepoda

Lipid storage by marine zooplankton is of considerable interest because of the role of lipids in seasonal life histories, the metabolic transformations of essential and other fatty acids in trophic transfers (Sargent \& Henderson 1986), and the potential of some lipid classes as measures of recent nutritional history (Hakanson 1987), respiration rate (Ohman \& Runge 1994), or reproductive potential (Ohman 1987) of some zooplankton taxa. However, often it is impractical to sort and extract lipids from large numbers of zooplankton samples at sea or during the course of experimental work in the laboratory, so it has become common practice to freeze and store zooplankton for subsequent lipid extraction and analysis (e.g. Hagen et al. 1993, Ohman \& Runge 1994, Miller \& Morgan 1995). Although early workers (e.g. Lee et al. 1971) carried out immediate extraction of lipids from tissues of live zooplankton aboard research vessels and some continue to do so (e.g. Kattner \& Krause 1987, Drits et al. 1994), it has not been fully resolved whether the freezing process results in quantitative changes in lipid

\footnotetext{
·E-mail: mohman@ucsd.edu
}

content or in qualitative changes in lipid class composition. Lee \& Hirota (1973) stated that they found no difference between lipids of Calanus (= Neocalanus) plumchrus from frozen and freshly extracted copepods, but provided no data on the subject. The issue requires resolution to ensure the validity of lipid analyses used in ecological studies.

Also unresolved is the appropriate temperature at which frozen zooplankton must be stored. Although it is accepted that temperatures of $-70^{\circ} \mathrm{C}$ or below are necessary to arrest the activity of lipases and other enzymes (Scopes 1994), such low temperature freezers are not always available for shipboard research. Enzymatic degradation of Artemia lipids occurred when animals were stored at $-20^{\circ} \mathrm{C}$ (Sasaki \& Capuzzo 1984). The possibility of non-enzymatic oxidation of polyunsaturated lipids also remains a concern. For marine copepods it is not clear whether storage at commonly available freezer temperatures $\left(-20\right.$ to $\left.-15^{\circ} \mathrm{C}\right)$ is acceptable if animals cannot be extracted for several months. This note therefore examines the effects of freezing and storage temperature on the lipid content and lipid class composition of the copepod Calanus pacificus californicus Brodsky (hereafter, C. pacificus).

To compare lipids extracted from fresh and frozen copepods, Calanus pacificus copepodid stage $V(\mathrm{CV})$ were collected on 4 June within $2 \mathrm{~km}$ of the pier at Scripps Institution of Oceanography (near $32^{\circ} 52^{\prime} \mathrm{N}$, $117^{\circ} 16^{\prime} \mathrm{W}$ ), with a $0.5 \mathrm{~m}, 333 \mu \mathrm{m}$ mesh net. One lot of sorted CVs was added live directly into $2: 1$ (v:v) $\mathrm{CH}_{3} \mathrm{Cl}: \mathrm{MeOH}$ (high-performance liquid chromatography grade), purged with $\mathrm{N}_{2}$ gas, then placed at $4^{\circ} \mathrm{C}$ in the dark. A second lot was frozen on Nitex mesh disks in liquid $\mathrm{N}_{2}$. Animals were removed from liquid $\mathrm{N}_{2}$ after several days and extracted exactly as for the live animals. Following ca $48 \mathrm{~h}$ extraction at $4^{\circ} \mathrm{C}$ (Ohman 1988), copepods were removed to tared aluminum boats, dried at $55^{\circ} \mathrm{C}$ overnight, then weighed 
on a Cahn electrobalance to determine lipid-free dry mass. For each lipid extraction 9 individuals were pooled ( $n=7$ replicates of fresh copepods and $n=8$ of frozen copepods). Lipid extracts were dried with $\mathrm{N}_{2}$ gas then resuspended in pure $\mathrm{CH}_{3} \mathrm{Cl}$, purged with $\mathrm{N}_{2}$, and kept at $-15^{\circ} \mathrm{C}$ for 3 to $4 \mathrm{~d}$ prior to analysis on an Iatroscan.

To compare the effects of different storage temperatures, copepods were collected in the San Diego Trough $\left(32^{\circ} 50^{\prime} \mathrm{N}, 117^{\circ} 39^{\prime} \mathrm{W}\right.$ ) with a $1 \mathrm{~m}^{2}$ MOCNESS (Wiebe et al. 1985) on 13 June 1992. The collection was split and promptly frozen in liquid $\mathrm{N}_{2}$ after removal of excess water by gentle vacuum. One fraction was transferred to a ship's freezer at $-20^{\circ} \mathrm{C}$ and the other maintained over liquid $\mathrm{N}_{2}$. Ashore, the first fraction was transferred to a freezer that lacked a defrost cycle, whose air temperature was approximately $-15^{\circ} \mathrm{C}$. The second fraction was transferred from liquid nitrogen to a freezer maintained below $-80^{\circ} \mathrm{C}$. On 24-25 May 1993, after 1 yr in cold storage, Calanus pacificus adult females were sorted and their lipids extracted under nitrogen as above.

Chromatographic separation of lipids was done on SIII Chromarods developed in hexane: diethyl ether:formic acid $(82: 18: 0.1, \mathrm{v}: \mathrm{v}: \mathrm{v})$ for either 26 or 35 min, after which time chromarods were scanned twice at $30 \mathrm{~s}$ $\mathrm{scan}^{-1}$ Lipid solutions were spotted in duplicate and quantified on a calibrated Mark V Iatroscan (TLC-FID) as described in Ohman \& Runge (1994). Alpha levels for Mann-Whitney $U$-tests were corrected for multiple testing based on the Bonferroni inequality (Miller 1981).

No significant difference was found between fresh and frozen Calanus pacificus CV in total lipid content, lipid-free dry mass, or lipid as a percentage of total dry mass (Table 1; p > 0.05, Mann-Whitney $U$-test) In a more detailed analysis of lipid class composition, there was no detectable difference in. wax ester, triacylglycerol, sterol, or polar lipid content (Fig. 1) in the 2 treatments. There was a difference in free fatty acid content $(p<0.01$; Fig. 1). Free fatty acids were detectable in only 2 of the 7 extractions of fresh animals $10.05 \pm$ $0.09 \mu \mathrm{g} \mathrm{copepod}^{-1}, \bar{x} \pm 95 \%$ ) while small quantities were detected in all. 8 of the extractions of frozen animals $\left(\bar{x}=0.86 \pm 0.19 \mu \mathrm{g} \mathrm{copepod}^{-1}\right)$. This free fatty acid

Table 1. Composition of Calanus pacificus CV when lipids were extracted from elther fresh or frozen copepods

\begin{tabular}{|c|c|c|}
\hline & $\begin{array}{c}\text { Fresh } \\
(\bar{x} \pm 95 \%, \mathrm{n}=7)\end{array}$ & $\begin{array}{c}\text { Frozen } \\
(\bar{x} \pm 95 \circ, \mathrm{u}, \mathrm{n}=8)\end{array}$ \\
\hline Total lipid & $44.9 \pm 8.4 \mu \mathrm{g}$ & $39.7 \pm 6.7 \mu g$ \\
\hline Lipid-free dry mass & $99.3 \pm 8.3 \mu \mathrm{g}$ & $91.4 \pm 5.5 \mu \mathrm{g}$ \\
\hline Lipid ( $\%$ total dry mass) & $30.9 \pm 4.0 \%$ & $30.1 \pm 3.2 \%$ \\
\hline
\end{tabular}

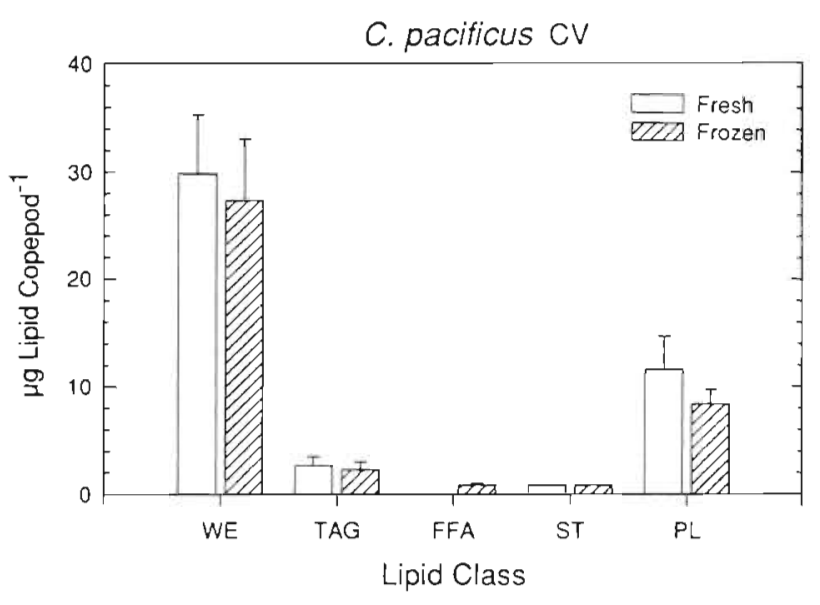

Fig. 1. Lipid class composition $(\bar{x} \pm 95 \%)$ of fresh and frozen specimens of Calanus pacificus copepodid V. WE: wax esters; TAG: triacylglycerols; FFA: free fatty acids; ST: sterols PL: polar lipids

content averaged $0.1 \%$ of the total lipid content of fresh and $2.2 \%$ of frozen animals.

The lipid composition of Calanus pacificus females after 1 yr storage at $-15^{\circ} \mathrm{C}$ was substantially different from that of copepods maintained at $-80^{\circ} \mathrm{C}$ (see chromatograms in Fig. 2) Polar lipids averaged $23.3 \pm$ $4.8 \mu \mathrm{g} \mathrm{copepod}^{-1}(\bar{X} \pm \mathrm{SD})$ in animals kept at $-80^{\circ} \mathrm{C}$, but only $5.8 \pm 0.4 \mu \mathrm{g}$ copepod $^{-1}$ in animals kept at $-15^{\circ} \mathrm{C}$.

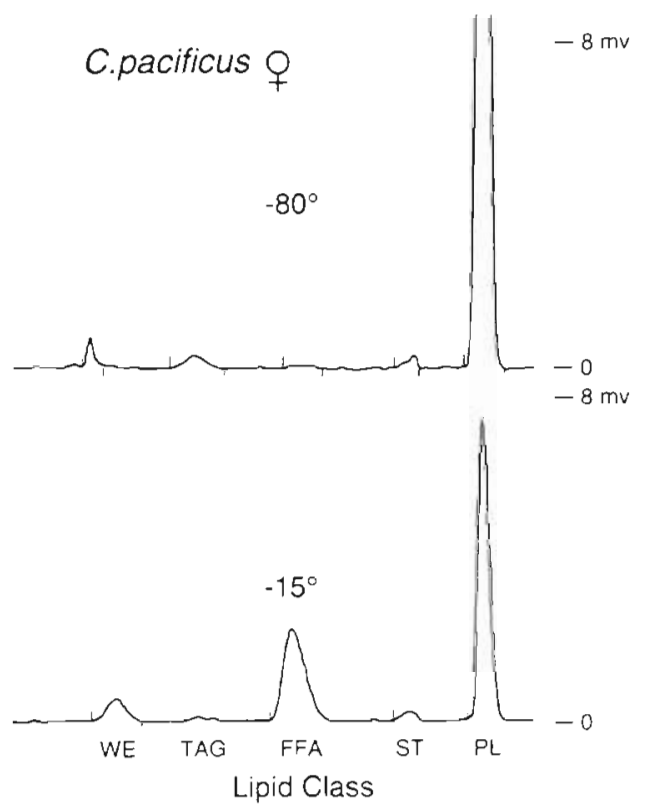

Fig. 2. Chromatograms from Iatroscan TLC-FID analysis of lipids extracted from adult female Calanus pacificus after storage for 1 yr storage at either $-80^{\circ} \mathrm{C}$ (upper panel) or $-15^{\circ} \mathrm{C}$ (lower panel). Note that the ordinate in both chromatograms is scaled from 0 to $8 \mathrm{mv}$. Vertical tics on chromatograms indicate the beginning and ending of each peak 
Free fatty acids averaged $0.9 \pm 0.3 \mu \mathrm{g} \mathrm{copepod}^{-1}$ in $C$. pacificus females maintained at the lower temperature and $7.5 \pm 0.8 \mu \mathrm{g} \mathrm{copepod}^{-1}$ at the higher temperature. Free fatty acids averaged $3.2 \%$ of total lipids from $C$. pacificus females stored at $-80^{\circ} \mathrm{C}$ and $43.4 \%$ of total lipids from females stored at $-15^{\circ} \mathrm{C}$.

These results show that no effect of freezing was measurable on copepod total lipid content, dry mass, or most of the individual lipid classes. Provided excess water is removed, ice crystal formation does not seem to disrupt the exoskeleton sufficiently to cause significant losses of lipids, including the wax esters so conspicuously located in lipid sacs or otherwise dispersed within the body cavity in many calanoid copepods (Sargent \& Henderson 1986). When thawing, copepods must be kept chilled and sorted quickly, as lipids can be released from the anal pore and other body openings if animals begin to warm (author's pers. obs.)

The small increase in free fatty acids (ca $0.8 \mu \mathrm{g}$ copepod $^{-1}$ ) from copepods frozen and kept briefly in liquid nitrogen suggests that the freezing process slightly improved the extraction efficiency for free fatty acids, perhaps by minor disruption of cell membranes. Comparable values of free fatty acids (typically 0.2 to $1.0 \mu \mathrm{g}$ copepod $^{-1}$ ) have been measured for 5 different copepod species (Ohman 1988, Ohman \& Runge 1994), suggesting that this is a characteristic minimum for frozen animals as determined by the techniques used in this laboratory

Temperatures of -15 to $-20^{\circ} \mathrm{C}$ are unacceptable for sample storage, apparently because of the activity of lipases and other enzymes. Saski \& Capuzzo's (1984) analysis of Artemia lipids illustrated that enzymatic hydrolysis was detectable after $7 \mathrm{~d}$ storage at $-20^{\circ} \mathrm{C}$. They found no evidence of non-enzymatic oxidative degradation. At temperatures of -15 to $-25^{\circ} \mathrm{C}$, salts crystallize, leaving enzymes as concentrated solutes where 'a few weeks of storage may do a lot of harm' (Scopes 1994). The observation in the present study of decreased polar lipids (here equivalent to phospholipids) in parallel with increased free fatty acids is consistent with the results of Saski \& Capuzzo (1984) showing enzymatic hydrolysis of phospholipids during storage. However, the amount of polar lipid loss measured here was more than twice the increase in mass of free fatty acids. Thus, attempts to 'add' the measured free fatty acid to phospholipid or another lipid class will surely generate biased results. Improper storage conditions are quite likely the source of the unusually high free fatty acid levels (to $40 \%$ of total lipids of female Calanus helgolandicus) reported by Gatten et al. (1979).

Freezing zooplankton in liquid nitrogen has a number of advantages. The ultralow temperature $\left(-196^{\circ} \mathrm{C}\right.$ for the liquid phase) promotes virtually immediate freezing with minimal temperature gradients within tissues. The activity of lipases and other enzymes is arrested. The nitrogen atmosphere inhibits lipid oxidation. Thus, where freezing copepods and other zooplankton is necessary for lipid studies, the best course is to freeze animals in liquid nitrogen and maintain them either in this medium or in a freezer below $-70^{\circ} \mathrm{C}$. Where storage over liquid nitrogen or in a freezer below $-70^{\circ} \mathrm{C}$ is not possible, it is advisable to immediately extract fresh animals then store the lipid extracts in solution at -15 to $-20^{\circ} \mathrm{C}$. Such extracts can be stored for periods of at least several weeks (Kates 1986). However, because of the susceptibility of extracted lipids to hydrolysis and peroxidation, lipid extracts should be kept under $\mathrm{N}_{2}$ gas, in solvents bubbled with $\mathrm{N}_{2}$ a antioxidants may be added (Kates 1986). Such precautions will improve the quantitative measure of zooplankton lipids in ecological studies.

Acknowledgements. I thank Luiz Fernandez for assistance with Iatroscan analysis. This study was supported in part by NSF OCE90-19639.

\section{LITERATURE CITED}

Drits AV, Pasternak AF, Kosobokova KN (1994) Physiological characteristics of the antarctic copepod Calanoides acutus during late summer in the Weddell Sea. Hydrobiologia 292/293:201-207

Gatten RR, Comer EDS, Kilvington CC, Sargent JR (1979) A seasonal survey of lipids in Calanus helgolandicus from the English Channel. In: Naylor E, Hartnoll RG (eds) Cyclic phenomena in marine plants and animals. Pergamon, New York, p 275-284

Hagen W. Kattner G, Graeve M (1993) Calanoides acutus and Calanus propinquus, antarctic copepods with different lipid storage modes via wax esters or triacylglycerols. Mar Ecol Prog Ser 97:135-142

Hakanson JL (1987) The feeding condition of Calanus pacificus and other zooplankton in relation to phytoplankton pigments in the California Current. Limnol Oceanogr 32:881-894

Kates M (1986) Techniques of lipidology. Isolation, analysis and identification of lipids, 2nd edn. In: Work TS, Work E (eds) Laboratory techniques in biochemistry and molecular biology. Elsevier, New York, p 269-610

Kattner G, Krause M (1987) Changes in lipids during the development of Calanus finmarchicus s.l. from copepodid 1 to adult. Mar Biol 96:511-518

Lee RF, Hirota J (1973) Wax esters in tropical zooplankton and nekton and the geographical distribution of wax esters in marine copepods. Limnol Oceanogr 18:227-239

Lee RF, Hirota J, Barnett AM (1971) Distribution and importance of wax esters in marine copepods and other zooplankton. Deep Sea Res 18:1147-1165

Miller CB, Morgan CA (1995) Storage lipids of Calanus finmarchicus in the Gulf of Maine, a data report. College of Oceanic and Atmospheric Sciences, Oregon State University, Data Report, Corvallis, p 1-15

Miller RG Jr (1981) Simultaneous statistical inference. McGraw Hill, New York 
Ohman MD (1987) Energy sources for recruitment of the subantarctic copepod Neocalanus tonsus. Limnol Oceanogr 32:1317-1.330

Ohman MD (1988) Sources of variability in measurements of copepod lipids and gut fluorescence in the California Current coastal zone. Mar Ecol Prog Ser 42 $143-153$

Ohman MD, Runge JA (1994) Sustained fecundity when phytoplankton resources are in short supply: omnivory by Calanus finmarchicus in the Gulf of St. Lawrence. Limnol Oceanogr 39:21-36

This note was presented by N. D. Holland (Senior Editorial Advisor), La Jolla, California, USA
Sargent JR, Henderson RJ (1986) Lipids. In: Corner EDS. O'Hara SCM (eds) The biological chemistry of marine copepods. Oxford Univ Press, Oxford, p 59-108

Sasaki GC, Capuzzo JM (1984) Degradation of Artemia lipids under storage. Comp Biochem Physiol 78B:525-531

Scopes RK (1994) Protein purification. Principles and practice, 3rd edn. Springer-Verlag, New York

Wiebe $\mathrm{PH}$, Morton AW, Bradley AM, Backus RH, Craddock JE, Barber V, Cowles TJ, Flierl GR (1985) New developments in the MOCNESS, an apparatus for sampling zooplankton and micronekton. Mar Biol 87:313-323

Manuscript first received: March 22, 1995

Revised version accepted: July 10, 1995 